\title{
Agricultural Terms of Trade in Pakistan
}

\author{
Abdul Aleem Khan and Kalim Hyder \\ SZABIST \\ Karachi, Pakistan
}

\begin{abstract}
:
The government in Pakistan is designing new policies to cope up with the requirements of free trade regime. Agriculture apart from being the largest sector is also one of the most affected sectors of the economy. Changes in the tariffs and subsidies structure have largely affected the domestic input and output prices and the consumer prices. The question now is that whether the prospects for the people depending on crop income have improved in terms of profitability and standard of living or not?
\end{abstract}

\section{INTRODUCTION}

In the wake of the liberalized trade regime, agricultural sector in Pakistan is undergoing structural adjustments such as liberalization of prices, eliminating export taxes and other trade restrictions and reducing agricultural subsidies. Pricing policies of the government and local and international trade environment have a major impact on the profitability, employment, and incomes in agriculture sector, and living standards and the poverty levels in the rural areas. Due to the dominance of agricultural sector in the economy and its backward and forward linkages, the changes in the value added, employment and prices in this sector would significantly affect the overall economic growth and employment in the country.

This paper aims to find the relative price changes in the crop sector to explore whether the profitability in the sector has improved or deteriorated. It also aims to see the impact of price changes on the standard of living of the farmers. For this purpose various terms of trade have been calculated. The terms of trade for crop sector are defined as the ratio of the index of prices received by the crop sector and the index of prices paid by the sector. To see the profitability in the sector the relative price changes between the output prices and input prices are calculated and to find the changes in the standard of living, the terms of trade between the producer prices and the consumer prices are calculated. In order to account for changes in productivity and population 'real per capita income terms of trade' are also calculated. To see the impact of partially (only output side) free trade scenario on the agricultural prices, profitability and the standard of living of the farmers two further indices have been calculated using international crop prices with respect to domestic consumer and input prices.

This paper is divided into five sections. The second section is the literature review which is further divided into two parts, the role of agricultural prices in agricultural growth and development, and the review of the earlier studies on agricultural terms of trade. In the third section we brief the methodology. The fourth section presents empirical findings and finally the fifth section concludes the paper.

\section{LITERATURE REVIEW}

\section{a) Role of Agricultural Prices in Agricultural Growth and Development:}

Since late 1970 s there has been a deliberate policy of the government to reduce subsidies on inputs. But at the same time the government was increasing the support prices of agricultural outputs. The increasing input costs were offset by the rising support prices and the profitability in the crop sector continued to increase slowly. Recently, in the wake of the IMF structural adjustment programs and the new emerging international trade scenario, the government, apart from eliminating input subsidies, has also reduced support prices for various crops. This has initiated a debate over agricultural prices.

The debate has boiled down to two different, widely accepted, views. One view is that the government must support the agricultural prices and the farmers must be protected from the decline in market prices of the agricultural commodities. Brown, Gilbert T. (1978) [1] claims that high prices in agricultural sector not only have implications for an efficient use of resources but can also shift the production function upwards by price-induced technological and institutional innovations and infrastructural investment in rural areas.

The other view is that the support prices and subsidies have made agriculture highly dependent on government support and in order to survive in the WTO trade regime the sector must become highly competitive, efficient and self dependent. Faiz and Tahir(1988) [2], have shown that an increase in producer prices of crops results in an increase in gains to the producer but at the same time it also results in a decline in consumer surplus. If on the other hand the producer prices decline and so the consumer prices then consumers are the gainers and producers are the losers. When government takes measures to reduce duties and subsidies on agricultural trade it results in increased efficiency in agricultural production due to increased competition from other countries (Chishti and Malik 2002) [3].

\section{b) Studies on Terms of Trade:}

Afzal (1977) [4] and Cheong and D'Silva(1984) [5] have computed the terms of trade indices by using the estimates of GDP at factor costs in current prices originating in 
agricultural and manufacturing sectors and their corresponding estimates at constant prices. Qureshi (1985) [6] has shown that the terms of trade had improved in favor of the farmers during the green revolution period but during the 1970 s they observed a mixed trend.

Zahid and Hyder (1986) [7] study the effects of relative price changes on the agricultural sector. They have calculated agricultural terms of trade for the period 197384. The results of Zahid and Hyder's study show that the domestic terms of trade with respect to consumer prices show a mixed trend. The terms of trade index with respect to input prices remained above the base throughout the study period. Zahid and Hyder (1986) [7] believe that the agricultural sector in Pakistan appears to have become relatively worse off during the period 1973-83.

In this study we have calculated various indices using the price and production data from secondary sources for the period 1983-84 to 2002-03. Special consideration has been given to the changing international trade environment. We are interested to find the answer to the following questions:

- Are the crop incomes declining?

- Are the living standards of farmers improving?

- Why the share of non-crop agriculture value added is increasing?

- Has the purchasing power of the farmers increased?

- Has the profitability in the crop sector improved over the last twenty years?

- Are the agricultural terms of trade contributing to rising rural poverty? ${ }^{1}$

\section{RESEARCH METHODOLGY}

Data for the calculation of indices is taken for the period 1983-84 to 2002-03, from secondary data sources. Six types of terms of trade are calculated in this paper;

\section{I) Ratio of the domestic producer prices and the consumer prices}

First, the index of domestic prices received by farmers is calculated. Index of consumer prices was adjusted for the base year of 1983-84. To calculate index of domestic producer prices, twenty agricultural commodities were selected. ${ }^{2}$ The indices were calculated using Laspeyres Formula. The formula is stated below:

$$
P I=\sum_{j=1}^{n} W_{o j} \times\left(P_{i j} / P_{o j}\right) \times 100
$$

\footnotetext{
${ }^{1}$ Although poverty is not directly discussed yet the answers to the research questions will be helpful for deriving useful results and conclusions about poverty in rural areas.

${ }^{2}$ These commodities were wheat, rice, maize, bajra, jowar, barley, sugarcane, cotton, gram, moong, mash, masoor, onion, potato, tomato, mango, banana, apple, guava and citrus.
}

$\mathrm{PI}=$ Price Index for any group, $\mathrm{j}=$ commodity and $\mathrm{i}=$ year, Woj = Weight of commodity ' $j$ ' in the base year ' $o$ ', $\mathrm{Pij}=$ Current year price of commodity ' $\mathrm{j}$ ', Poj = Base year price of commodity ' $\mathrm{j}$ ', and $\mathrm{n}=20$.

And also,

$$
W=q_{o j} \times P_{o j} / \sum_{j=1}^{n} q_{o j} \times P_{o j}
$$

qoj = base year quantity of commodity ' $j$ '. $i=1983-84$ to 2002-03; j= 1 to $n$.

\section{II) Ratio of the international prices of crops to the prices of consumer goods.}

Two indices used to calculate these terms of trade are the index of international prices of crops which farmers can get in the international market and the index of consumer prices of goods. Eight commodities were selected to calculate the index of international prices of crops $^{3}$.

\section{III) Ratio of the domestic producer prices to the inputs prices.}

Index of prices of agricultural inputs was calculated to find the price trends of the agricultural inputs that farmers purchase domestically for crop production. Four major inputs i.e. fertilizer, light diesel oil, water, and pesticides were selected to compute this index.

\section{IV) Ratio of the international crop prices to the input prices.}

These terms of trade were calculated using the price index of eight agricultural commodities assuming that the farmers sell the commodities directly in the international market. In the denominator we had the price index of four agricultural inputs.

\section{V) Real Per Capita Income terms of trade (domestic).}

To account for changes in productivity and population, we have calculated 'Real Per Capita Income Terms of Trade'.

Real per capita income terms of trade were calculated by using Quantum Index of crop production and rural population index. Quantum Index of Agricultural Produce was calculated by taking the production of the twenty crops for all years and their prices for the base year. To compute the index of rural population, the rural population for all relevant years (1983-84 to 2002-03) was estimated.

The formula for quantum index is given below:

$$
Q I=\sum_{j=1}^{n} W_{o j} \times\left(q_{i j} / q_{o j}\right) \times 100
$$

\footnotetext{
${ }^{3}$ The commodities were rice, wheat, cotton, jowar, citrus fruits, banana, barley, and maize. The prices taken were producer prices.
} 
QI = Quantity Index, qij = output of the commodity ' $\mathrm{j}$ ' for the current year. And;

$$
W_{o j}=q_{o j} \times P_{o j} / \sum_{j=1}^{n} q_{o j} \times P_{o j}
$$

Population index was calculated by using this formula.

$$
\text { Pop } I=(\text { Pop i / Pop o }) \times 100
$$

Pop I $=$ Population Index, Pop $_{\mathrm{i}}=$ Current year population, and $\mathrm{Pop}_{\mathrm{o}}=$ Base year population.

VI) Real Per Capita Income terms of trade (international crop prices).

Method of calculation of these indices was same as the real per capita income terms of trade based on domestic crop prices. The only difference was that in order to calculate this index on the basis of international prices we took quantum index of those eight commodities of which the international prices are available.

\section{EMPIRICAL FINDINGS}

\section{STANDARD OF LIVING}

i) Ratio of the domestic, producer prices to the prices of the consumer goods.

The terms of trade for farmers have shown a mixed trend, however, throughout the period of study the index remained below the base year (see results in the table at the end). There was a period of only three years from 1997-98 to 1999-00 during which the terms of trade improved over the base year. In 1996-97 there was a significant drop in agricultural production of many crops due to pest attack. This resulted in an increase in producer prices in the subsequent years. The domestic terms of trade depict that, the purchasing power of the farmers has relatively decreased over the base year.

\section{ii) Real Per Capita Income Terms of Trade based on Domestic Prices}

The real per capita income terms of trade are calculated by multiplying the domestic terms of trade for producer and consumer prices with the adjustment factor. The adjustment factor was computed by dividing the quantum index with the rural population index.

iii) Ratio of the international prices of crops to the prices of consumer goods.

For most of the period the terms of trade with respect to international crop prices and domestic consumer goods prices were below the base year. If we compare the international prices of crops with the domestic producer prices of crops, we can see that the international prices have not risen at the pace domestic prices have. This shows how the subsidies provided by developed countries to their farmers have kept the international prices low and have marginalized the farmers of developing countries.

\section{iv) Real Per Capita Income Terms of Trade based on} International Prices.

These terms of trade were calculated to see how the variation in per capita production affects terms of trade based on international crop prices. The results show that because the production index has increased more than the population index, the real per capita income terms of trade have slightly improved.

\section{THE PROFITABILITY IN CROP SECTOR}

i) Ratio of the domestic producer prices of crops to the major agricultural inputs' prices.

These terms of trade have been computed to find whether the profitability in the crop sector has increased or decreased over the twenty years. The terms of trade have remained below the base year except for the period from 1997 to 2000. The index of domestic prices of inputs has increased more than the index of domestic producer prices of crops. The reason of rapidly rising input prices is that the government has gradually removed the subsidies on the agricultural inputs. The results show that the profitability in the crop sector has declined over the study period. Three years of profitability, 1997-98 to 1999-00, coincide with the three years of rising standard of living.

ii) Ratio of the international crop prices to the prices of major agricultural inputs they buy domestically.

The results show that the terms of trade for farmers have declined over the base year except for four years (1989-90, and 1995 to 1998). Even the exchange rate factor could not offset this decline. If we assume to have a managed float the decline in the terms of trade for the year 2002-03 over the base year would be around 42 percent.

\section{CONCLUSION}

The results show that the purchasing power of the farmers has relatively decreased and so they can buy fewer goods for their personal consumption. This shows that the standard of living of farmers who solely depend on crop/farm income has worsened. Although the terms of trade with respect to producer prices and consumer prices were not in favor of the farmers, the rise in production and larger sales volumes due to increase in productivity have let the farmers maintain their farm incomes. The real per capita farm incomes have shown a modest rise. There were some years during which real per capita rural income did not increase and even decreased. 
If the farmers sell their products in the international market under unrestricted trade scenario (and assuming that the developed countries continue to provide agricultural subsidies to their farmers) then the farmers would face a further decline in their purchasing power and deterioration in their living standards due to falling international crop prices. It is worth mentioning that if the developed countries remove the agricultural subsidies they provide to their farmers the prices in the international market would rise giving greater margins to Pakistani farmers. The consumer prices of agricultural commodities would then increase. The profitability for the farmers has declined in the crop sector. This establishes a very strong argument that because of the declining profitability in the crop sector the farmers are now looking for other means of income, for instance livestock and manufacturing sectors, to meet their consumption requirements. It depicts that since, the profitability in the sector has not improved, the farmers depending only on crop income must have become victims of rising poverty. Although we have not established any direct link between terms of trade and poverty but it seems that the worsening terms of trade are contributing to the rising poverty.

As far as the government policies regarding agricultural subsidies and prices are concerned it can be suggested that if the government reduces or removes the input subsidies it must increase the support prices so that the farmers are not further marginalized.

\section{REFERENCES}

[1] Brown, Gilbert T. (1978). "Agricultural Pricing policies in Developing Countries". In Theodore W.Shultz (ed.), Distortions of Agricultural Incentives. Bloomington: Indiana University Press.

[2] Muhammad, Faiz and Tahir,Sayyid (1988) "Agricultural Prices in Pakistan: A multimarket Analysis". The Pakistan Development Review, winter.

[3] Chishti, Anwar F. and Malik, Waqar (2002). WTO's Trade Liberalization, Agricultural Growth, and Poverty Alleviation in Pakistan. Pakistan Institute of Development Economics.

[4] Afzal, M.(1977). "Parity Pricing as an approach to price support programmes", The Pakistan Development Review, 16(3).

[5] Cheong, Kee Cheok, and Emmanuel H.D'Silva (1984). Prices, "Terms of Trade and the Role of Government in Pakistan's Agriculture". Washington, D.C.: World Bank. (World Bank Staff Working Paper No.643)

[6] Qureshi, Sarfraz, K. (1985). Domestic terms of trade and public policy for agriculture in Pakistan, Pakistan Development Review, 24(3 and 4).

[7] Zahid, N. Shahid and Hyder, S. Sajjad (1986). Pakistan's agricultural terms of trade: 1973-74 to 1983-84. Pakistan Journal of Applied Economics. Applied Economics and Research Centre, University of Karachi. 


\begin{tabular}{|c|c|c|c|c|c|c|c|c|c|c|c|c|c|}
\hline Period & $\begin{array}{c}\text { Domestic } \\
\text { Terms of } \\
\text { Trade (TOT) }\end{array}$ & $\begin{array}{c}\text { Index of } \\
\text { Producer } \\
\text { Prices }\end{array}$ & $\begin{array}{c}\text { Index of } \\
\text { Consumer } \\
\text { Prices }\end{array}$ & $\begin{array}{c}\text { Quantum } \\
\text { Index of } \\
\text { Agricultural } \\
\text { Production } \\
\text { (Domestic) }\end{array}$ & $\begin{array}{c}\text { Index of } \\
\text { Rural } \\
\text { Population }\end{array}$ & \begin{tabular}{|c|} 
Real Per \\
Capita \\
Income \\
TOT \\
(Domestic)
\end{tabular} & \begin{tabular}{|c|} 
Terms \\
of \\
Trade \\
(Int.prices)
\end{tabular} & \begin{tabular}{|c|} 
Index of \\
International \\
Producer \\
Prices
\end{tabular} & $\begin{array}{l}\text { Quantum } \\
\text { Index of } \\
\text { Agricultural } \\
\text { Production } \\
\text { ( International) }\end{array}$ & $\begin{array}{c}\text { Real Per } \\
\text { Capita } \\
\text { Income } \\
\text { TOT } \\
\text { (Int. Prices) }\end{array}$ & $\begin{array}{c}\text { TOT } \\
\text { w.r.t. } \\
\text { domestic } \\
\text { Input } \\
\text { Prices }\end{array}$ & $\begin{array}{c}\begin{array}{c}\text { Index } \\
\text { of } \\
\text { Input Prices }\end{array} \\
\end{array}$ & $\begin{array}{l}\text { TOT w.r.t. } \\
\text { International } \\
\text { output and } \\
\text { domestic } \\
\text { input prices }\end{array}$ \\
\hline 1983-84 & 100.00 & 100.00 & 100.00 & 100.00 & 100.00 & 100.00 & 100.00 & 100.00 & 100.00 & 100.00 & 100.00 & 100.00 & 100.00 \\
\hline 1984-85 & 97.22 & 102.73 & 105.67 & 115.03 & 102.23 & 109.40 & 98.83 & 104.43 & 126.06 & 121.87 & 90.76 & 113.20 & 92.26 \\
\hline $1985-86$ & 94.63 & 104.35 & 110.27 & 122.69 & 104.51 & 111.10 & 88.40 & 97.48 & 141.07 & 119.33 & 93.50 & 111.61 & 87.34 \\
\hline 1986-87 & 93.92 & 107.29 & 114.24 & 126.66 & 106.84 & 111.34 & 79.09 & 90.35 & 143.24 & 106.04 & 92.67 & 115.77 & 78.04 \\
\hline 1987-88 & 96.49 & 117.17 & 121.43 & 129.71 & 109.22 & 114.59 & 83.98 & 101.97 & 150.50 & 115.72 & 94.69 & 123.74 & 82.41 \\
\hline 1988-89 & 96.28 & 129.05 & 134.04 & 136.13 & 111.66 & 117.38 & 96.55 & 129.42 & 156.72 & 135.51 & 97.38 & 132.52 & 97.66 \\
\hline $1989-90$ & 92.32 & 131.22 & 142.14 & 138.44 & 114.15 & 111.96 & 115.65 & 164.38 & 157.89 & 159.97 & 85.96 & 152.64 & 107.69 \\
\hline $1990-91$ & 92.09 & 147.47 & 160.13 & 143.95 & 116.69 & 113.61 & 105.34 & 168.68 & 167.17 & 150.90 & 85.46 & 172.57 & 97.75 \\
\hline $1991-92$ & 95.13 & 166.99 & 175.53 & 162.01 & 121.35 & 127.01 & 96.37 & 169.15 & 193.61 & 153.75 & 95.94 & 174.06 & 97.18 \\
\hline 1992-93 & 93.94 & 180.16 & 191.78 & 146.60 & 123.86 & 111.18 & 93.44 & 179.20 & 166.94 & 125.94 & 98.75 & 182.43 & 98.23 \\
\hline 1993-94 & 98.91 & 210.89 & 213.21 & 151.92 & 126.32 & 118.96 & 91.66 & 195.42 & 163.03 & 118.30 & 96.68 & 218.14 & 89.59 \\
\hline 1994-95 & 95.69 & 230.37 & 240.76 & 160.42 & 128.75 & 119.22 & 97.80 & 235.46 & 172.64 & 131.13 & 92.76 & 248.35 & 94.81 \\
\hline 1995-96 & 92.18 & 245.90 & 266.76 & 173.70 & 131.25 & 121.99 & 109.78 & 292.85 & 190.51 & 159.34 & 98.52 & 249.59 & 117.33 \\
\hline 1996-97 & 97.46 & 290.65 & 298.23 & 168.95 & 133.86 & 123.00 & 119.89 & 357.54 & 182.77 & 163.69 & 98.56 & 294.88 & 121.25 \\
\hline $1997-98$ & 100.71 & 323.83 & 321.54 & 179.60 & 136.63 & 132.38 & 101.72 & 327.07 & 189.72 & 141.25 & 104.16 & 310.90 & 105.20 \\
\hline 1998-99 & 103.95 & 353.37 & 339.96 & 180.31 & 140.70 & 133.21 & 95.74 & 325.48 & 184.67 & 125.66 & 106.02 & 333.32 & 97.65 \\
\hline 1999-00 & 101.01 & 355.74 & 352.17 & 197.23 & 143.73 & 138.61 & 89.59 & 315.50 & 218.84 & 136.40 & 104.62 & 340.02 & 92.79 \\
\hline 2000-01 & 96.61 & 355.22 & 367.68 & 186.33 & 147.00 & 122.46 & 93.16 & 342.54 & 204.58 & 129.66 & 99.21 & 358.04 & 95.67 \\
\hline 2001-02 & 97.13 & 369.76 & 380.70 & 177.58 & 150.18 & 114.85 & 100.49 & 382.56 & 194.85 & 130.38 & 95.85 & 385.79 & 99.16 \\
\hline 2002-03 & 99.61 & 390.96 & 392.50 & 185.63 & 153.26 & 120.64 & 96.26 & 377.81 & 198.10 & 124.41 & 95.14 & 410.93 & 91.94 \\
\hline
\end{tabular}

